\title{
Na cenzurowanym - trudne relacje między kobietami w powieściach Zofii Niedźwiedzkiej
}

Barbara Wąsik

(Uniwersytet Pedagogiczny im. KEN w Krakowie)

Interesując się relacjami między kobietami na przełomie XIX i XX w., jako podstawowe źródło informacji postanowiłam wykorzystać powstające w tej epoce teksty literackie. Mam nadzieję, że ich analiza pozwoli mi choć częściowo zrekonstruować istniejące wtedy wzory zachowań i stosunków międzyludzkich, a także stereotypy kulturowe i normy postępowania stanowiące element ówczesnej świadomości społecznej. Skupiłam się na powieści realistycznej, która - zdaniem Michała Głowińskiego - „odpowiada (i odpowiadała) najbardziej podstawowym wizjom świata, [jako - B. W.] że wchłania je niejako i czyni elementem wypowiedzi [...]”, i która dzięki temu dociera (i docierała) do masowego czytelnika i ma najszerszy zasięg czytelniczy spośród innych gatunków. Przy tym, jak zauważa Bronisław Geremek: „Gdy przedmiotem badania są mechanizmy mentalne i zachowania zbiorowe, nie ma znaczenia, czy badamy zjawisko lub zdarzenie, które kiedyś autentycznie miało miejsce, czy też wytwory wyobraźni pisarskiej [...]”, gdyż z racji tego, że literatura opisuje życie codzienne, po wzięciu w nawias poziomu informacyjności na temat świata przedstawionego, odsłoni się nam mechanizm sposobu myślenia danej epoki. Taki kierunek badań wymaga od nas „odmiennej lektury, przejścia od

1 M. Głowiński, Powieśc i prawda, w: idem, Gry powieściowe. Szkice z teorii i historii form narracyjnych, Warszawa 1973, s. 20. Jerzy Topolski (Problemy metodologiczne korzystania ze źródet literackich w badaniu historycznym, w: Dzieto literackie jako źódto historyczne, pod red. Z. Stefanowskiej i J. Sławińskiego, Warszawa 1978, s. 14-15) uważa, iż pisarz kreuje świat przedstawiony, bazując na szkielecie, którym są „klasy faktów, zachowań, typów ludzkich, prawidłowości itd.”, następnie uszczegóławia go informacjami, także o charakterze fikcyjnym. Idealizuje tak wytworzoną rzeczywistość poprzez skupienie uwagi na wymienionych wyżej głównych elementach, uznając je za podstawę świata przedstawionego. Owo „Wypełnienie modelu materiałem faktograficznym o charakterze fikcyjnym w zasadzie nie podważa prawdy z poziomu klas faktów odzwierciedlającej istotne cechy rzeczywistości”. 
postaci i sytuacji pierwszego planu do tła, zwrócenia baczniejszej uwagi na utwory i gatunki literackie pośledniejszej jakości”.

Zgodnie z tym zaleceniem zadecydowałam, że przykładów do rekonstrukcji relacji między kobietami dostarczy mi - zaliczana do tzw. literatury kobiecej ${ }^{3}$ - dziś już niemal zapomniana twórczość Zofii Niedźwiedzkiej . Autorka nie zdobyła specjalnego uznania także wśród ówczesnych znawców ${ }^{5}$, ale jej proza cieszyła się w pierwszej ćwierci XX wieku dużą popularnością, zwłaszcza wśród

2 B. Geremek, Fabuta, konwencja i źródto, w: Dzieto literackie..., op. cit., s. 114-116. Oczywiście, na co zwraca uwagę Ryszarda Czepulis-Rastenis (Znaczenie prozy obyczajowej XIX wieku dla badań ówczesnej świadomości i stosunków spotecznych, w: ibidem, s. 261-281), niezbędna jest ostrożność w bezpośrednim wnioskowaniu. Obszernego i kompetentnego przeglądu literatury przedmiotu na ten temat dokonała przed laty Małgorzata Rowicka, ona także w sposób najbardziej konsekwentny wykorzystała powieści jako źródło informacji o interesujących ją zagadnieniach (Sceny lektury w polskiej powieści realistycznej drugiej potowy XIX w. (zabór rosyjski), w: Instytucje - publiczność - sytuacje lektury. Studia, red. J. Kostecki, t. 3, Warszawa 1991, s. 98-180. Zob. też J. Kostecki, M. Rowicka, Biblioteki w zaborze rosyjskim w powieściach realistycznych II potowy XIX wieku, w: Biblioteki i ksiażki w literaturze, red. K. Bednarska-Ruszajowa, Kraków 1998, s. 75-91).

3 Pojęcie to weszło do obiegu krytycznoliterackiego w drugiej połowie XIX w. i od początku używano go często w sposób lekceważący, a nawet pogardliwy (G. Borkowska, Metafora drożḋ̇y: co to jest literatura/poezja kobieca?, „Teksty Drugie” 1995, nr 3/4 (33/34), s. 33; K. Kłosińska, Kobieta autorka, ibidem, s. 87-112). Literatura kobieca stanowi szczególny przypadek tzw. literatury popularnej. Zob. na ten temat m.in. M. Bujnicka, Bohaterki romansu popularnego (z zagadnień konstrukcji), w: Postać $w$ dziele literackim, red. Cz. Niedzielski, J. Speina, Torun 1982, s. 71-83; A. Martuszewska, „Ta trzecia". Problemy literatury popularnej, Gdańsk 1997; I. Poniatowska, Modernizm bez granic. Wielkie tematy nowoczesnosici w polskich powieściach popularnych drugiej potowy XIX wieku, Warszawa 2014; T. Żabski, Literatura popularna, w: Stownik literatury popularnej, red. T. Żabski, wyd. 2, Wrocław 2006, s. 310-316.

4 Powieściopisarka (pseud. Bohowityn) żyła w latach 1872-1921. Pochodziła z Wołynia, lecz ostatni okres życia spędziła w Petersburgu. Rekonstrukcji biografii pisarki ze szczątkowych informacji oraz analizy jej utworów dokonała Katarzyna Dunaj-Dziecielska w niepublikowanej pracy doktorskiej Twórczośc literacka Zofii Niedżwiedzkiej (pseudonim Bohowityn) - wybrane problemy, napisanej pod kierunkiem prof. Tadeusza Linknera i obronionej w 2013 r. na Wydziale Filologicznym Uniwersytetu Gdańskiego. Jej fragmenty dostępne są w formie artykułów (Siłaczki, emancypantki, dekadentki. Galeria postaci kobiecych w powieści „Nasi dekadenci” Zofii Niedżwiedzkiej, w: Znane zapomniane. Z literatury polskiej XIX i XX wieku, red. K. Eremus i T. Linkner, Gdańsk 2011, s. 81-96; O „takich” się nie mówi, czyli „Kobieta z przesztościq" Zofii Niedźwiedzkiej, w: Cate miasto dysze oburzeniem... Skandal w literaturze XIX i XX wieku, red. K. Eremus i T. Linkner, Gdańsk 2012, s. 63-71; „Umiem kochać tylko krótkotrwata namiętnościq wędrowca”. Portret amanta w „Dziejach mężatek” Zofii Niedżwiedzkiej, w: „Wszystko lubię to, co pani... ”. Literackie portrety amantów i studentów, red. K. Eremus i T. Linkner, Gdańsk 2013, s. 105-115; Dobry duch domu i „Belzebub w spódnicy”, czyli portrety ciotek w powieści „Nasi dekadenci” Zofii Niedżwiedzkiej, w: Do ostatniego lokaja... W kreggu rodziny i znajomych, red. K. Eremus i T. Linkner, Gdańsk 2013, s. 47-55). Zob. też A. Jopek, Niedźwiedzka z Kozieradzkich Zofia, w: Polski stownik biograficzny, t. 22, Wrocław 1977, s. 754. Poza tym nazwisko i dorobek pisarki wspominane bywa jedynie przy okazji omawiania jakiegoś szerszego zagadnienia.

5 Podobnie jak inne ówczesne pisarki minorum gentium, w ogólnych opracowaniach z epoki zaistniała marginalne. Jej nazwisko odnalazłam w zaledwie trzech spośród ośmiu wytypowanych syntez. Władysław Okręt (Rocznik Naukowo-Literacko-Artystyczny (encyklopedyczny) na rok 1905, Warszawa 1905) podał jedynie datę urodzenia i tytuły powieści, a Cecylia Walewska (Ruch kobiecy w Polsce, cz. 1, Warszawa 1909, s. 26) i Antoni Potocki (Polska literatura wspótczesna, cz. 2: Kult jednostki 1890-1910, Warszawa 1912, s. 297) wymienili tylko (wśród innych) jej nazwisko lub pseudonim. 
kobiet ${ }^{6}$.Wykorzystałam cztery spomiędzy sześciu jej powieści: Stoneczniki (I90I), Wyzyskiwani (1903), Kobieta z przesztościq (1911), Dzieje mężatek (1915), w których owe kontakty występują7.

Znaczna część relacji międzyludzkich jest wyraźnie nacechowana aksjologicznie, przy czym miewają one zarówno charakter pozytywny (np. więziotwórczy, stanowiący wyraz troski o innego), jak i negatywny (np. krępujący swobodę czy będący formą nacisku, prowadzący do odrzucenia lub upokorzenia drugiego). Skupię się na tych drugich, uwzględniając i strategie kobiet osaczających, i obronne reakcje kobiety osaczanej. Interesować mnie będą obszary życia podlegające wartościowaniu (np. pochodzenie, uroda, wyznawane ideały, aspiracje, styl życia), a także społeczne źródła stosowanych przez kobiety kryteriów oceny, w tym odpowiedź na pytanie, na ile są one wytworem internalizacji norm narzucanych przez mężczyzn („męskiej dominacji”, jak by to ujął Pierre Bourdieu ${ }^{8}$ ), a na ile czynników innego rodzaju (w tym szczególnych doświadczeń samych kobiet).

Podstawy teoretyczne, a zwłaszcza aparaturę pojęciową, umożliwiające analizę owych relacji, zapożyczyłam z tzw. trzeciej socjologii, która za przedmiot badań obiera przestrzeń międzyludzką, czyli ogół relacji zachodzących między „istotami społecznymi”9. Naczelną kategorią badawczą będzie dla mnie zdarzenie społeczne, a więc „działania wielości ludzi wobec siebie, w powiązaniu $z$ innymi, w ramach pewnej wspólnej dla działających sytuacji”。 . Szczegółowo przyjrzę się zwłaszcza bezpośrednim formom kontaktu - sytuacje realnego spotkania są bowiem o wiele bogatsze niż relacje o charakterze pośrednim, gdyż recepcja Innego (uczestnika

6 W latach 1899-1924 ukazało się na rynku co najmniej 25 wydań dziewięciu książek Niedźwiedzkiej. Publikowały je w zdecydowanej większości firmy z największych ośrodków wydawniczych (Warszawy, Krakowa i Lwowa), przy czym zainteresowanie edytorów wygasło już trzy lata po śmierci pisarki (obecnie niektóre $\mathrm{z}$ nich funkcjonują jednak w formie e-booków). Przeszukane źródła: katalogi NUKAT i KARO; katalogi internetowe bibliotek: Narodowej i Jagiellońskiej oraz kartkowy BJ; kartoteka „Bibliografii polskiej 1901-1939” przechowywana w BN; I. Teresińska, Niedźwiedzka Zofia, w: Dawni pisarze polscy. Od poczatków piśmiennictwa do Mtodej Polski: przewodnik biograficzny i bibliograficzny, t. 3: Mia-R, Warszawa 2002, s. 125; Z. Szweykowski, J. Maciejewski, Literatura pozytywizmu i Mtodej Polski: hasta osobowe M-Ś. Bibliografia Literatury Polskiej „Nowy Korbut”, t. 15, Warszawa 1977, s. 110-111; A. Jopek, op. cit.

7 Oznaczenia ułatwiające cytacje: Sł - Stoneczniki, W - Wyzyskiwani, Kzp - Kobieta z przesztościa, Dm - Dzieje mężatek; cyframi arabskimi oznaczam numery stron. Fragmenty Kobiety z przesztościq przytaczam za wydaniem z roku 1923, a Dzieje mężatek z 1919. W powieściach Nasi dekadenci (1899) oraz Z gruzów (1905) nie znalazłam interesujących mnie informacji. W cytatach zachowałam pisownię oryginału.

8 P. Bourdieu, Męska dominacja, tłum. L. Kopciewicz, Warszawa 2004. W XIX w. na problem ten zwracał uwagę m.in. John S. Mill (Poddaństwo kobiet, wyd. 2, tłum. M. Ch[yrzyńska], Kraków 1887).

9 P. Sztompka, Kapitat spoteczny. Teoria przestrzeni międzyludzkiej, Kraków 2016, s. 12; idem, Życie codzienne - temat najnowszej socjologii, w: Socjologia codzienności, red. P. Sztompka i M. Boguni-Borowska, Kraków 2008, s. 23.

10 P. Sztompka, Życie codzienne..., op. cit., s. 24. 
dialogu) angażuje jednocześnie wiele zmysłów i środków komunikacji, takich jak mowa ciała, mimika, gest ${ }^{\text {II }}$. Choć na przebieg oraz treść kontaktu bezpośrednio wpływają głównie motywacje i intencje, lub inaczej - cele, które chcą osiągnąć partnerzy dialogu, to ramą dla wszelkich relacji ${ }^{\mathrm{I}}$ jest szeroko rozumiana kultura danego czasu i miejsca ${ }^{\mathrm{I} 3}$. Dokonując analizy, będę więc brała pod uwagę m.in.: kontekst społeczny, w którym zachodzą relacje; „gęstość otoczenia”, czyli udział osób trzecich; „lokum relacji” - miejsce, w którym obowiązują określone normy; czy są to relacje silne, czy słabe; jak na ich przebieg wpływają normy kulturowe; jakie są sankcje społeczne za ich nieprzestrzeganie; czy relacje mają charakter autoteliczny, czy instrumentalny.

Wyróżniłam pięć rodzajów relacji między kobietami: I. rodzinne, 2. towarzyskie, 3. sąsiedzkie, 4. zawodowe lub związane $z$ innym rodzajem aktywności pozadomowej, 5. przygodne, z nieznajomymi (obcymi). Tworzą one kontinuum - od kontaktów prywatnych po publiczne. Zacznę od przyjrzenia się relacjom matka-córka, gdyż na matce spoczywa obowiązek wprowadzenia córki w świat dorosłych, inicjacji, która w dużym stopniu decyduje o całej trajektorii kobiecych losów.

\section{RELACJE RODZINNE - MACIERZYŃSKIE}

Powszechna zależność kobiet od mężczyzn powodowała, że matki swoją troską obejmowały przede wszystkim córki. Przedmiotem ich zabiegów było takie ich wychowanie, które zagwarantowałoby im zainteresowanie ze strony bogatego mężczyzny, zapewniłoby zatem w przyszłości pożądane bezpieczeństwo finansowe. Mniejsze znaczenie miało, jakim człowiekiem jest przyszły mąż, czy cieszy się dobrą opinią, w jakim jest wieku. Liczył się jego status ekonomiczny, a czasami tylko społeczny (np. śluby ze zbankrutowanymi arystokratami w celu uzyskania tytułu). W praktyce ten typ troski ustanawiał relacje traumatyczne, nadawał młodym kobietom status „podrzędnego”, zabijając w nich ducha indywidualizmu; matki nie traktowały ich - w odróżnieniu od synów - jak ludzi myślących, mających prawo do podejmowania i kształtowania życia według własnych pragnień i przekonań.

\section{》Dwaj starsi synowie [Oktawii Czatyhorskiej - B.W.], doścignąwszy pełnoletności, prędko się pozbyli jarzma matki; ale córki, których}

11 Idem, Kapitat spoteczny..., op. cit., s. 91.

12 W uzasadnionych wypadkach zamiast terminu „relacja” używać będę określeń „stosunek” lub „więź”.

13 P. Sztompka, Kapitat spoteczny..., op. cit., s. 92. W innej tradycji badawczej używa się w tym wypadku określenia „sytuacja komunikacyjna w skali makrospołecznej”. 
okrutna tradycja starych obyczajów trzymała w zależności, stały się prawdziwymi jej ofiarami. Nie wolno im było nie tylko postępować, ale nawet myśleć podług swej woli. Musiały być echem matki w najmniejszych drobiazgach, które się ich same tyczyły. Pełna miłości własnej, obawiając się, aby wyższy, a dla niej jedyny świat, nie zarzucił jej czegokolwiek w postępowaniu, wysilała się na dogodzenie potworowi próżności i głupoty, tworząc ze swych córek lalki, niewolnice, w których wszystko było fałszywe, nienaturalne. Zdawało jej się, że wypełnia najsumienniej swe obowiązki, dając dowody wielkiego przywiązania do dzieci i zdziwiłaby się ogromnie, gdyby jej ktoś powiedział, że te córki to także ludzie: że one umieją czuć, myśleć, że każda ma odrębne usposobienie, które należy szanować, że nie można, bez wielkiej krzywdy dla nich i dla społeczeństwa, urabiać na jedną modłę bezmyślne jednostki. Czatyhorska nie uznawała podobnych pojęć, zwąc je demokratyczną emancypacją, dobrą dla kobiet motłochu; wytwarzała więc ze swych córek, niby na obstalunek, światowe panny i prezentowała je $z$ dumą przedstawicielom „beau mond'u”. Panny [...] chodziły, mówiły, kłaniały się bez zarzutu, paplały obcymi językami, któżby więc badał, czy włożono w nie duszę...myśli? (S1, s. 6-7).

Relacje matka-córka w powieściach Niedźwiedzkiej, naznaczone dominacją pierwszej z nich, miały więc najczęściej charakter instrumentalny. Rozmowy między nimi dotyczyły np. właściwego ubioru, zachowania się w towarzystwie, wykształcenia przydatnego w późniejszym życiu jako matki i żony; rodzicielki ganiły przy tym wszelkie odstępstwa od przyjętego wzorca kobiety. Oktawię Czatyhorską martwiło m.in. to, że wyedukowaną poza domem Halę nudziły rozmowy salonowe, że mówiła po polsku, a nie po francusku, że nie poruszała się z należytą kokieterią, że zaprzyjaźniła się z dziewczyną z folwarku, że nie chciała wyjść za mąż, odstraszając swym zachowaniem potencjalnych kandydatów.

\Córki były jej pociechą, ale znów ta Halina!... [...] Po skończeniu pensji nie chciała powracać do Zakroczymia, pomimo rozkazu matki i pozostała w Krakowie, u stryja swego Romana Czatyhorskiego, znakomitego uczonego, z którym podróżowała prawie dwa lata. Przed kilku miesiącami wróciła do domu, ale do czegóż podobna? Śmieją się z niej w arystokratycznym kole, nazywają „bas bleu” patentowaną starą panną w przyszłości. I to może łatwo nastąpić, gdyż nawet taką 
partię, jak książę Ryszard, traktuje lekceważąco. Jakich ma środków użyć, żeby zmienić jej usposobienie? (S1, s. 57) ${ }^{\mathrm{I}}$.

W szczególny sposób matki dbały o moralność córek. Starały się odizolować je od osób ze złą reputacją, a także od nieodpowiednich ich zdaniem mężczyzn. Muśkiewiczowa, mieszkająca z bratem, zwracała mu uwagę na niewłaściwe zachowanie jego żony (Nora głosiła nowe, modne poglądy, miała osobną sypialnię, wracała do domu nawet po północy), gdyż jej córki mogłyby je kopiować. Szczególnie ubolewała nad kontaktami Nory z niezamężną, lecz mającą dziecko Hanną:

\} \quad - [ \ldots ] \text { Taka pani Hanna! Mój Boże! Za moich czasów nie wymawiano } by głośno jej nazwiska, a tu jest nauczycielką, karesowaną, obsługiwaną. [...] A niech zdycha i innych nie gorszy! Wstyd mi, że córki moje o niej wiedzą (Kzp, s. I2).

Matki kontrolowały wszystkie aspekty życia dziewcząt: sprawdzały im garderobę, cenzurowały sposób wypowiadania się, ingerowały w wygląd (Hala musiała dwa razy przebierać się do posiłku; zasugerowano jej przekłucie uszu, aby „przypodobała się mężczyznom”; S1, s. 38-39) i sposób spania. Gdy jedna z córek bliźniaczek Muśkiewiczowej we śnie zmieniła pozycję,

\ Budzi ją ktoś.

- Felciu, leżysz na wznak. Połóż się zaraz na bok. przeżegnaj się i śpij - mówi Muśkiewiczowa.

Mumijka pokornie przewraca się na bok. Ręką, która tylko co ściskała we śnie dużą i miękką dłoń męską, kładzie na piersi znak krzyża. Nie może zasnąć, chociaż usiłuje, i boi się myśleć o śnie prześnionym, i coś jej go wciąż do ucha powtarza (Kzp, s. IO2).

Kontrola Muśkiewiczowej obejmowała nawet rytuał wstawania bliźniaczek (codziennie ten sam schemat: ziewnięcie, znak krzyża, staranne ubieranie się), a także ich fizjologię:

\- Miałaś wczoraj żołądek, Felciu?

- Miałam.

- A ty, Teciu?

$-\mathrm{N}$... nie. 
- A to trzeba na to poradzić - ożywia się mama.

Dalej następują pytania o różne szczegóły. Biedne mumie krępują się, ale odpowiadają z pokorą i z bezwzględną szczerością (Kzp, s. Ioz).

Oczywiście sprawdzano także korespondencję i rekwirowano niepożądane książki, a za te Oktawia Czatyhorska uznawała m.in. prace medyczne:

\- Nie jestem dzieckiem; dobór literatury mojej do mnie należy. Co zaś do książki, kazałaś wyrzucić, jest to fizjologia, przysłana mi przez stryja, człowieka wielkiej nauki i wielkiej moralności.

- Tam były rzeczy, o których panna nie powinna wiedzieć. Ale wy, emancypantki nie wstydzicie się niczego, nawet słuchać wykładów medycznych wobec studentów i patrzeć na obnażone trupy. Tak wy rozumiecie przyzwoitość.

- Nie wiem, czy nauka może być nieprzyzwoitą. Powiem ci tylko, mamo, że daleko więcej wstydziłabym się obnażać ciało na balach $\mathrm{i}$ teatrach, jak to robią kobiety z całą świadomością celu tej nagości, być przedmiotem cynicznych spojrzeń i słuchać dwuznacznych komplementów, jakimi nas darzą mężczyźni, a także padać ofiarą późniejszych ich rozpraw o naszych zaletach fizycznych, aniżeli słuchać poważnych wykładów o cierpieniach ludzkich, wśród poważnie myślących jednostek. [...]

- [...] zechciej widzieć we mnie człowieka myślącego, znającego swe prawa i pozwól mi odjechać za granicę, gdzie chcę studiować filozofię, będąc przez stryja doskonale przygotowaną w tym zakresie.

- Nigdy! - zawołała gwałtownie Czatyhorska - nigdy nie zezwolę na to, żebyś upadła w oczach ludzi, włócząc się sama, gdzieś za granicami, bez opieki!

- Po cóż mi opieka, przecie jestem już od dawna pełnoletnią?

- Wobec świata kobieta jest wtenczas pełnoletnią i może sama sobą kierować, gdy jest już zupełnie starą (Sł, s. 92-93).

Oktawia dbała również o pozory pobożności swoich córek. Kiedy Hala nie chciała uczestniczyć w rekolekcjach przed Bożym Narodzeniem, matka stwierdziła, że bardzo by się jej przydały, a przede wszystkim oznajmiła, że „wobec ludzi nie masz prawa uchybiać przyjętym zwyczajom, ani narażać mego nazwiska na obmowę. Ponieważ całe nasze towarzystwo uczęszcza na rekolekcje, więc i ty tam być musisz z rodzeństwem, choćby dla oka ludzkiego" (S1, s. 344). Widać tu ogromną siłę, z jaką opinia społeczna wpływała na sposób myślenia jednostki. 
Córki musiały się tłumaczyć $\mathrm{z}$ każdego swego kroku (nawet samotny spacer po parku godził w dobre imię rodziny). Charakterystyczne było zachowanie bliźniaczek, gdy młodsza córka Muśkiewiczowej, Zula, chciała zabrać je na spotkanie $\mathrm{z}$ Andrzejem ${ }^{\mathrm{I5}}$ :

$$
\begin{aligned}
& \gg \text { - Mamy nie ma - odrzekły jednocześnie. } \\
& \text { - Właśnie dlatego możecie pójść. Zróbcie choć raz wyłom... Coś } \\
& \text { samodzielnie... Wyobraźcie sobie powrót mamy, jej przerażenie, no... } \\
& \text { szacunek dla was. } \\
& \text { - Och, co by to było! - szepnęła jedna. } \\
& \text { Druga potwierdziła grozę wahaniem głowy. } \\
& \text { - Nic nie byłoby mumijki! [...]. Chodźcie ze mną do pracowni Da- } \\
& \text { niela. Pokaże wam posągi nagich mężczyzn. Nie widziałyście nigdy. } \\
& \text { Ciekawe. } \\
& \text { Mumijki śmiały się, rumieniły i spuszczały oczy, wciągając w siebie } \\
& \text { ożywiony głos Zuli, jak świeży powiew łąk (Kzp, s. 8I-82). }
\end{aligned}
$$

Za naganne uważano zwłaszcza przebywanie sam na sam z młodym mężczyzną, i to bez względu na powód spotkania (np. zawodowy). Jako przykład może posłużyć reakcja Zuli, pozującej do obrazu św. Cecylii, gdy do pracowni wszedł niespodziewanie znajomy malarza Kreticza, wspomniany Andrzej:

$$
\begin{aligned}
& \gg \quad \text { - Ale mamie pan nie powie? } \\
& \text { - Powiem, że pani była pod moją opieką. } \\
& \text { - Nie... nic... Zupełnie nie trzeba mówić. Już bym straciła prawo } \\
& \text { wychodzenia. Ratuję się Zosią Ziębicką, moją koleżanką, do której } \\
& \text { chodzę. Ona często mnie odwiedza i potwierdza wszystko, co ja mówię } \\
& \text { (Kzp, s. 29). }
\end{aligned}
$$

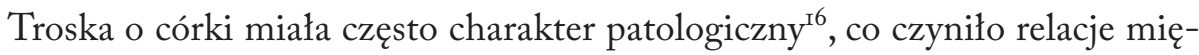
dzypokoleniowe słabymi i zimnymi, niespójnymi z intuicyjnym pojmowaniem pojęcia miłości macierzyńskiej. Dla Muśkiewiczowej Felcia i Tecia miały być przede

15 „Fundamentem w wytworzeniu się u naczelnych wewnętrznego policjanta, czyli zjawiska samokontroli, jest orientacja na akceptację i satysfakcjonowanie innych; w wypadku dziecka będzie to poszukiwanie akceptacji dorosłych [...]" (J. Wasilewski, Retoryka dominacji, Warszawa 2006, s. 252).

16 Określenia „patologiczna troska” użyła Nel Noddings w swojej koncepcji troski bezpośredniej odnośnie do sytuacji, w której dbałość o obcych jest ważniejsza niż o bliskie nam osoby (zob. M. Uliński, Etyka troski i jej pogranicza, Kraków 2012, s. 76). Moim zdaniem stosowanie tego terminu należałoby rozszerzyć także do opisu sytuacji, gdy troska o najbliższych jest tylko przykrywką do troski przede wszystkim o siebie. 
wszystkim pociechą i opieką na starość, dać jej wnuczęta, nawet jeżeli ceną miało być ich szczęście. Ale by tak się stało, musiały być bezwolne i nawet po ślubie całkowicie podporządkowane matce:

\ Rzeczywiście Muśkiewiczowa zawsze ogromnie dbała o zdrowie córek. Jak mądry pasożyt, oszczędzający ciało, z którego pije soki, starała się, żeby były doskonale odżywione, miały wszelkie wygody, żeby wyrosły duże i rozwinęły się dobrze.

Mumijki były pulchne, zażywne.

Patrzy na nie z czułością. [...]

Czarną stroną tej korony powodzeń byli zięciowie. Nie wie, czy z nimi poradzi. Bywają okrutni, egoiści. Walka z nimi trudna.

A nuż zbuntują córki... (Kzp, s. IOI-IO2) ${ }^{\mathrm{I} 7}$.

Reakcja Hortensji na niepowodzenie jej planów była zawsze gwałtowna. Gdy zorientowała się, że „Nic nie będzie z małżeństwa [...], a to dlatego, że Zula nie zachowuje się, jak «panna $z$ towarzystwa». Następstwem tego wniosku było rozwinięcie na całej linii tresury" (Kzp, s. Ioo). Poczucie bezradności, przechodzące we wściekłość, Muśkiewiczowa wyładowywała na starszych córkach oraz na służbie:
\Czujność jej spotęgowała się. Nic w domu nie mogło stać się, żadna inna wola nie mogła wydźwignąć z nieistnienia najmniejszego ruchu, bez jej wiedzy. Była obecna wszędzie. Oczami badała, pytała. Węszyła ukrywane myśli domowych. Napadała śmiało na podwładnych.
W nocy nawet nie sypiała (Kzp, s. Ioo).

Charakter stosunków panujących w domu korespondował z wyglądem pomieszczeń, w których toczyło się życie codzienne. W pokoju Hortensji Muśkiewiczowej, w którym mieszkała z córkami
\Wszystko było jednakowe. Wszędzie panowała czystość i zarazem jakiś nastrój, który mówił, że w tym państwie rządzi jedna wszechwładna wola, jedna energia. Czuło się, że w różnych zagłębieniach pokoju mieszkają cierpkie przestrogi, despotyczne naginania, jedna wola, wywłaszczająca współmieszkanki z indywidualności (Kzp, s. I4).

17 Jednak kiedy Zula niespodziewanie i bez jej wiedzy wyszła za mąż za Oskonnego, matka była zła tylko do czasu wizyty w nowym domu córki: „Wspaniałe mieszkanie, przepych, olśniły Muśkiewiczową. Zapomniała nawet o wymówkach, którymi miała obsypać Oskonnego" (Kzp, s. 143). 
Tak ukształtowana przestrzeń stawała się swoistym komunikatem znamionującym dominację oraz środkiem wpływu ${ }^{\mathrm{I} 8}$.

W odpowiedzi na kontrolę matki, obejmującą zarówno ciało, jak i psychikę, córki prezentowały trzy różne postawy ${ }^{19}$. Pierwsza to bezrefleksyjne przyjmowanie autorytarnych rządów, jak w przypadku bliźniaczek Feli i Teci. Kiedy coś działo się nie po myśli Muśkiewiczowej, np. Zula buntowała się przeciwko jej rządom, „Mumie drżały zupełnie nagie duszą i ciałem matki, oddane na jej pastwę, ciche, bezwolne, jak tresowane żelazną ręką zwierzęta” (Kzp, s. Ioo). Reagowały tak, choć im także marzyło się inne życie (zob. opisane wcześniej sceny snu jednej z nich czy reakcji obu na zaproszenie Zuli na spacer z Andrzejem).

Drugi typ postawy przyjmowały dziewczęta, które podporządkowywały się woli matki, chociaż wiedziały, że narzucone wybory nie przyniosą im szczęścia. Chłodna kalkulacja mówiła im jednak o możliwości polepszenia sytuacji finansowej. $\mathrm{Na}$ przykład córka Czatyhorskiej, Emma, gardziła mniej majętnymi ludźmi, a preferowała bogatszych ze względu na status społeczny i ekonomiczny, który się z tym wiązał. $Z$ tego powodu zrezygnowała z miłości do Gustawa Myszłowskiego. Gdy przyjmowała oświadczyny starego barona Greicha, „Oczy miała szeroko rozwarte, jakby w chwili przerażenia, ustami chwytała powietrze - zdawała się być bliską zemdlenia”. Jeszcze przed zaręczynami tak skomentowała swój związek:

\section{》- Dobrze ci żartować, Nino, a on dla mnie taki wstrętny. [...] - Cóż mam robić? Do wyboru nie mam wiele, a ten przynajmniej bogaty [...] nie mogę sobie wyobrazić miernego życia. Nie stworzonam do tego! (S1, s. 2I, I3I, I55).}

Decyzja córki spotkała się z całkowitą aprobatą matki.

Ostatni typ stanowily córki-buntowniczki. Zarówno Zula Muśkiewicz, jak i Halina Czatyhorska czynnie sprzeciwiały się woli matki. Pierwsza rozpoczęła proces

18 Zob. J. Wasilewski, op. cit., s. 64.

19 Takie modele relacji matka-córka Niedźwiedzka dostrzegała także w rodzinach aspirujących do tzw. warstw wyższych. Przykładowo, matka trzech córek, pani Drużbecka, mieszkająca w folwarku na skraju posiadłości zakroczymskiej, zwanym Samotrzaskiem, machinalnie naśladując we wszystkim dziedziczkę Oktawię Czatyhorską, również starała się wychować swoje córki na wielkie panie, tak by w przyszłości znalazły dobrych mężów i awansowały w hierarchii społecznej. Dlatego m.in. wysłała Jadzię na tę samą pensję, na której uczyła się Halina; choć sama nie znała francuskiego, kontrolowała książki czytane przez córki; ganiła je za brak gorsetu, który muszą nosić panie dobrze urodzone (S1, s. 105-109). Ponadto planowała zatrudnienie nauczycielki francuskiego oraz zakup karocy. Rezultaty jej zabiegów były zróżnicowane: jedna z córek, Irenka, ulegała jej wpływom; druga - Klocia początkowo podporządkowana, ostatecznie zbuntowała się i wyszła za mężczyznę równego jej statusem, ale którego kochała; trzecia - Jadzia prezentowała nowy typ kobiety: wykształconej i samodzielnej, która założyła pierwszą w okolicy aptekę prowadzoną przez kobiety. 
ucieczki od zamieszkania w oddzielnym pokoju, a nie (jak do tej pory) razem $\mathrm{z}$ matką i siostrami:

\- Nie możesz sobie wyobrazić, jak mnie to denerwuje, że ja nigdy do siebie nie należę. Ja przecież rozumiem, że życie naszej matki rozrasta się na rachunek naszych żyć. Biedne mumie to tylko akcesoria do zabarwienia jej istnienia. Ja nie mogę być tym... We mnie strasznie dużo „ja” człowieczego, ogrom egoizmu!... (Kzp, s. Iоз).

Gdy Hala postanowiła wyjechać za granicę, aby podjąć studia filozoficzne, i usłyszała od matki, że nie otrzyma ani pieniędzy, ani żadnej pomocy, wprost wypomniała Oktawii nierówne traktowanie dzieci:

\- Dla braci moich, mamo, nie miałaś tych słów ostrych, gdy, nie pytając cię o radę, trwonili ogromne sumy na zdrożne rzeczy.

- Na to oni mężczyźni! Ich opinia nie dotyka.

- Tworzą sami tę opinię, a zatem są dla siebie pobłażliwsi. Więc dlatego, że jestem kobietą, chcesz mię rzucić na pastwę nędzy za to, że ośmieliłam się zapragnąć swobody i światła, a braci moich, dlatego, że są mężczyznami, zaspakajasz szalone materialne wymagania, chociaż wiesz, na jaki użytek one idą?

- Zanadto jesteś zuchwałą, ośmielając się wtrącać w moje sprawy. Ojciec wasz zrobił mię dożywotniczką całej fortuny, a zatem dał mi prawo karania krnąbrnych dzieci.

- Krnąbrnych córek tylko! - rzekła Hala ze smutną ironią. - Ojciec powierzył ci w zaufaniu nasz majątek i naszą przyszłość, nie podejrzewając zapewne, że będziesz robiła różnicę między dziećmi - dlatego, że świat tę różnicę robi (S1, s. 94).

Hala uważała, że jej relacja z matką przypomina nieustającą walkę dwóch sił, „z których jedna stara się ujarzmić drugą, broniącą się wielce drapieżnie, jak ja to robię od pewnego czasu" (S1, s. 38). Dziewczyna zwierzała się swej przyjaciółce Jadzi, że

》 $\quad$ [...] Mama nawet nie uznaje córki za ludzi. Podług niej, są to pieńki [sic! - B. W.], które pod pozorem ich własnego szczęścia, rodzice przestawiają, jak im się podoba, na szachownicy życia, a których każdy krok, każde poruszenie duszy jest własnością świata, opinii. Przy takim zapatrywaniu, samodzielne moje dążności nie są wcale pożądanymi. Jestem też traktowaną w domu, jak małoletnia [...] (S1, s. 38). 
Przyczyny tego, że kobiety ulegają presji zawierania niechcianych małżeństw, bohaterka upatrywała w stanie ich świadomości społecznej:

》 - Po cóż więc te dziedziczki wielkich fortun oddają się tym poszukiwaczom? - Bo nie mają często innego wyjścia z gnębiącego koła przesądów; większość nie zdaje sobie sprawy z tej poniżającej roli: niewola upadla człowieka (Sł, s. 42).

\section{RELACJE TOWARZYSKIE - „INNA” VERSUS „UCZCIWE KOBIETY”}

Pod pojęciem „Inna” rozumiem taką kobietę, której wygląd, zachowanie, biografia itp. wykraczały poza granice wyznaczone przez normy obowiązujące w danej społeczności ${ }^{20}$. Jako owe „Inne” otoczenie traktowało np. kobiety z niższych sfer, które weszły do nowej dla nich, „lepszej” grupy przez małżeństwo, czy też kobiety $\mathrm{z}$ nieślubnym dzieckiem.

W pierwszej z tych sytuacji znalazła się np. wychowana na wsi dwudziestoletnia Ruta, żona starszego od niej Jerzego Trockiego, mieszkańca Warszawy obracającego się w kręgach arystokracji. Nowa rola społeczna dała jej nie tylko pewne prawa i przywileje, ale przede wszystkim narzuciła duży zakres obowiązków ${ }^{2 \mathrm{I}}$. Jej powinnością stało się m.in. organizowanie spotkań towarzyskich, np. five o’clocków, zwanych także reunionami, których szczerze nie znosiła („To psuło jej wesoły nastrój i w oczach [...] błądził pewien niepokój [...]”, „Ruta nie lubiła reunionów”, „Rozpoczynała się męka Ruty” - Dm, s. ıo, I3), gdyż wiedziała, że panie biorące udział w spotkaniu nie były jej przychylne, nie uważały jej za równą sobie, co wyraźnie dawały jej odczuć (,jej akcent nie warszawski, wywołuje tłumiony śmiech i złośliwe przedrzeźnianie tuż poza jej plecami”; „Każde złośliwe lub niechętne spojrzenie wytrącało ją z równowagi. Plątała słowa i nieraz milkła zniechęcona, gdy zauważyła, że umyślnie chcą jej dokuczyć”- Dm, s. Io). Także po opuszczeniu domu państwa Trockich kobiety nie szczędziły słów krytyki pod adresem organizatorki spotkania:

\section{》 Jerzowa jest strasznie głupia [...], mówiono o jej wielkiej mądrości, ale coś tego nie widać! I niech mi pani droga powie, skąd ona ma te stroje? Ani to ładne, ani modne. Śmieszna jest bardzo z tymi dziecinnymi ruchami, z tym akcentem, z ubraniem (Dm, s. I7).}

20 Według Wasilewskiego (op. cit., s. 239) ta forma dominacji opiera się na antynomii lepszy-gorszy.

21 P. Sztompka, Kapitat spoteczny..., op. cit., s. 132-133. 
Kontakty Ruty z kobietami miały charakter instrumentalny - dziewczyna po prostu wypełniała swoje obowiązki pani domu. Ponieważ jednak „cała przestrzeń międzyludzka jest także przestrzenią aksjo-normatywną" ${ }^{22}$, oceniano ją, stosując obowiązujące w nowym środowisku normy społeczne i kulturowe. Według nich nie sprawdzała się w swej roli, dlatego spotykały ją ze strony kobiet drwiny, złośliwości, dogryzania i uśmieszki podszyte ironią (Dm, s. IO-I7)23. Owa świadomość braku akceptacji powodowała, że „Czuła się niezgrabną i nieelegancką wobec świetnie ubranych, pewnych siebie pań [...]” (Dm, s. Io). Dodatkowo nie odczuwała wsparcia ze strony męża („Bolało ją najwięcej, że Jerzy był nieraz świadkiem jej upokorzenia i może podzielał niekorzystne o niej zdanie”- Dm, s. Io), czuła się jak intruz, a jej poczucie wyobcowania zwiększało się z dnia na dzień („Zmęczyłam się istotnie, ale nie fizycznie. Nie umiem być dystyngowaną panią domu" - Dm, s. I4). Ale trudności w nawiązaniu poprawnych relacji wynikały też $z$ tego, że stosowane wobec młodej pani Trockiej kryteria oceny wynikały z obcego dla niej i nieakceptowanego przez nią systemu wartości. Uważała bowiem, że otaczające ją kobiety nie potrafią samodzielnie myśleć, nie rozumieją tego, o czym mówią („Nie lubiła ich układnych, słodkich min, przesadnej grzeczności, zmrużonych złośliwie oczu, a niekiedy nawet ich ślicznej mowy" - Dm, s. Io), wręcz „Nie wiedziała o czym mówić z tymi paniami” (Dm, s. 13). Rucie nie podobał się także zakres tematów poruszanych przez nowo poznane kobiety: mówiły dużo, „obgadywały - chwaląc, jednym drgnieniem powiek wyśmiewały” (Dm, s. I4), lustrowały siebie nawzajem, oceniały wyłącznie powierzchowne cechy człowieka, nie próbowały zagłębić się w psychikę - to wszystko spowodowało, że dziewczyna uznawała rozmówczynie za „wystawowe lalki” oraz „komediantki”, które oszukiwały siebie i innych. Szwagierka dziewczyny, pani Grykolska, widząc jej stan, radziła wprost:

\section{\Przede wszystkim nie mów nigdy o swoich małostkach. Możesz prędzej przyznać się do tego, że życzysz śmierci człowiekowi, niż do tego, że ci imponują czymkolwiek bądź otaczający. Chodź rubasznie, pleć głupstwa, ubieraj się szkaradnie, ale rób to, wszystko z arogan- cją, z pewnością siebie, to jest z taką miną, jakby ci wszyscy ludzie, na których ci zależy, byli kapuścianymi głowami. Drwij z wszyst- kiego! Drwiny to straszna broń, to prawdziwa filozofia towarzyska (Dm, s. I4).}


Podobne zachowanie kobiet podczas balu u Monińskich spowodowało, że Inną poczuła się też pani Drużbecka. Gdy zaproszono ją wraz z córkami na przyjęcie, przyjechały nań - odpowiednio wystrojone - karocą kupioną specjalnie na tę okazję. Na miejscu okazało się, że bal zorganizowano nie tylko dla osób z wyższego towarzystwa, jak na początku myślały, ale dla całej okolicy, dlatego wśród bawiących znalazły się także rodziny niezbyt zamożne.

\section{\ Tłumy gości podzieliły się na kółka i kółeczka. Starsze patrycjuszki siedziały osobno, zamieniając niekiedy między sobą chłodne uwagi o zebranym towarzystwie; młodsze łączyły się uprzejmie z resztą go- ści. Wszystkie ubrane były bardzo skromnie, w lekkich, gustownych strojach. Aksamity i brylanty stroiły tylko panie najmniej zamożne. - Moja droga, jesteś zupełnie w stroju codziennym - mówiła jed- na z ozdób "grand mond'u" do księżnej Przemysławowej, siostry Monińskiej. \\ - Na rauty Monińskich nigdy się inaczej nie ubieram. Gdybym się dziś wystroiła, następnego roku szlachcianki porujnowałyby mężów, chcąc mi dorównać (S1, s. 280).}

Pojawił się nawet projekt, żeby zabawy taneczne urządzać w dwóch salach: jednej dla arystokracji, drugiej - dla plebejuszy, jednak pomysł upadł. Po balu rozwiały się marzenia Drużbeckiej o zaakceptowaniu jej i córek przez wyższe sfery, gdyż „nie uszły jej oka drwiące spojrzenia i powstrzymywane śmiechy, ani ucha - złośliwe komentarze, jakie sobie komunikowały o niej z cicha przedstawicielki high-life'u" (S1, s. 284, 313).

Przyczyną wykluczenia kobiety z „towarzystwa” mogło być także posiadanie nieślubnego dziecka. Hanna niechętnie chadzała m.in. na przyjęcia organizowane przez Norę Słowińską, gdyż

》 przybywające na rauty panie umiały zawsze otoczyć się nimbem kobiecej uczciwości, niedopuszczającej nic wspólnego z panną, o której mówiono, że ma dziecko. [...] Hanna stanowiła określoną największą wartość: zabierania ciągle myśli każdego z biesiadników. Była osnową, a wnosiła skrępowanie.

Panie $z$ „towarzystwa” usiłowały wydać się wobec niej najbardziej dystyngowanymi, zupełnie niedostępnymi dla wszystkich zakazanych uciech: przybierały ton królowych łaskawych, a nawet myślą nie znieważonych. Te zaś, które miały różne miłostki, flirciki tajemne, unikały 
Hanny, żeby nie były posądzone o powinowactwo z nią duchowe (Kzp, s. 78-79).

Podobnie traktowano kobietę także w miejscach publicznych. Spotkani w teatrze znajomi z przyjęć u Nory nie chcieli odwzajemnić Hannie nawet skinienia głowy („Z całego grona ukłon oddała tylko jedna młoda panna, mocno się zarumieniwszy, i flirtujący z nią młodzieniec" - Kzp, s. I28), pozostali udawali, że jej nie widzą. Inni celowo unikali spotkania $\mathrm{z}$ nią, by nie być źle odebranymi przez towarzystwo („Nic jej nie łączyło z tym bezimiennym tłumem, i miała wrażenie, że nieprzebyta przegroda zaczyna wyrastać między nią a resztą ludzi, zapełniających czas i przestrzeń” - Kzp, s. I29). Hanna antrakt spędziła samotnie, słysząc ciągłe śmiechy i żarty. Upokorzenie, którego doznała, spowodowało, że opuściła teatr jeszcze przed zakończeniem przedstawienia (Kzp, s. I28-I29).

\section{RELACJE SĄSIEDZKIE}

W powieściach Niedźwiedzkiej brak akceptacji dla kobiet, których życie nie pasowało do obowiązujących norm, cechował także stosunki sąsiedzkie. Najlepiej obrazują to sceny z życia wspomnianej Hanny, która samotnie wychowywała swą nieślubną córkę, Wiesię. Sąsiadki kontrolowały każde odwiedziny u niej, zwłaszcza mężczyzn, podejrzewając dziewczynę o świadczenie usług seksualnych. Cała kamienica żyła jej życiem, wszyscy byli żądni nowych informacji. Oto jak sąsiadki zareagowały na wizytę Daniela, artysty i współpracownika Hanny:

\footnotetext{
\- $Z$ kawalerem przyszła - dobiegł ją szept z przeciwka, z kuchni na wpół otwartej.

- To ten, co zawsze przychodzi.
}

Sługi zaraz poleciały do pań z wiadomością, że „tamta z dzieckiem” już przyprowadziła tego ładnego mężczyznę, co to często przychodzi. Uczciwe kobiety słuchały, zaledwie oddychając ze zgrozy i pragnienia dowiedzenia się jak najwięcej szczegółów... (Kzp, s. 33).

Podobnie komentowały odwiedziny Jana Szumskiego, z którym Hanna zaprzyjaźniła się, pracując w komitecie zajmującym się opieką nad więźniami: „Do tej panny chodzi teraz jakiś chudziak bez wąsów. Zdechlak. Wiosny nie dożyje. To dopiero gust..."(Kzp, s. I13). 
Niechęć do młodej matki przelewano także na pomagającą jej nianię. Gdy wracała ze spaceru, sąsiadki zbiorowo obrażały nie tylko ją i Hannę, ale także Wiesię, a nawet psa, Pika:

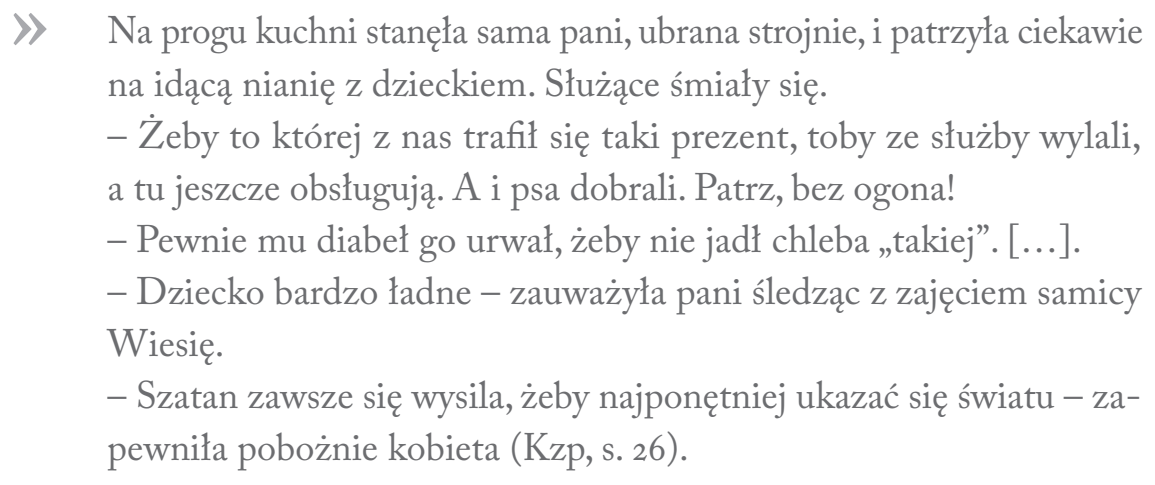

Sąsiadki nie potrafily uszanować nawet śmierci niani. Pod pozorem obejrzenia wystawionego ciała zmarłej, chciały bowiem „zobaczyć, jakie to muszą być wspaniałości u «takiej»" (Kzp, s. I48).

\section{RELACJE ZAWODOWE LUB ZWIĄZANE Z INNYM RODZAJEM AKTYWNOŚCI POZADOMOWEJ}

Stałym miejscem spotkań kobiet było w oczywisty sposób miejsce pracy. W analizowanych utworach wystąpiły trzy warianty takich relacji - związane z pracą najemną, prowadzeniem własnej firmy i z działalnością charytatywną.

Wielu upokorzeń od swej pracodawczyni doznawała nauczycielka domowa, Ewa Starkiewiczówna. Pani Zurakowska, która w przeszłości sama miała wykonywać ten zawód, a awansowała w hierarchii społecznej tylko dzięki małżeństwu z bogatym człowiekiem, którego nie kochała, na każdym kroku, choćby samym tonem wypowiedzi, podkreślała swoją wyższość i upokarzała Ewę. Podczas spotkania u państwa Widzkich, gdy pociechy zaczęły się bić, kobieta usłyszała: „Trzeba było ciągle uważać na nich - zwróciła się Zurakowska octowo grzecznie”. Podczas kolacji „Głos Zurakowskiej skierowany do niej rozlegał się co chwila, uderzając ją po nerwach”, co powodowało, że „Za każdym odezwaniem się Zurakowskiej, uwaga całego towarzystwa przenosiła się na Ewę i na chwilę ucichała wesoła rozmowa, zaprawiona wybuchami śmiechu"(W, s. 22). Trzeba jednak wspomnieć, że sposób traktowania Starkiewiczówny nie wynikał tylko z relacji pracownikpracodawca, ale także z przyczyn osobistych. Zurakowska próbowała wyswatać swego brata z Teresą Widzką - panną całkiem niebrzydką, a w dodatku z dużym 
posagiem ${ }^{24}$, lecz Czesławowi podobała się nauczycielka, więc Zurakowska zwolniła ją pod pozorem dbania o moralność córki („Mam nadzieję, że pani nie będzie miała do mnie pretensji o to, że, mając córkę, muszę czuwać nad jej moralnością" - W, s. 309 $)^{25}$. Stosunek szef-podwładny zakłada dominację pracodawcy, jednakże sposób, w jaki Zurakowska zlecała zadania, był nadmiernie oschły i ostry, co świadczy o lekceważeniu nauczycielki przez pracodawczynię oraz braku troski o zachowanie twarzy przez Ewę ${ }^{26}$.

W innej sytuacji znalazła się Jadwiga Drużbecka, właścicielka pierwszej „kobiecej” apteki w okolicy. $Z$ racji tego, że założyły ją dwie panie, firma od razu stała się tematem plotek, oszczerstw i złośliwych komentarzy. Najbardziej krytykowały postępowy pomysł właśnie kobiety:

\section{》 - Sodoma i Gomora! - oburzały się cnotliwe gęsi. - Co też te kobiety wyrabiają? A do igły! Do garnków! Dlaczego rząd nie położy tamy takiemu zgorszeniu? - Dwie panny mieszkają same; mężczyźni mają do nich wstęp o każdej godzinie dnia i nocy... Ta panna Drużbecka to ładna osóbka i sprytna widocznie; zrozumiała, że handel jej gładko pójdzie - syczała opinia (S1, s. 327).}

Właściciel drugiej apteki, pan Borzymowicz, $\mathrm{w}$ walce $\mathrm{z}$ konkurencją postanowił wykorzystać „oszczerstwa, przesąd wiekowy, siłę mocniejszego”. Rozpuszczał plotki o otruciach lekarstwami pochodzącymi z apteki Drużbeckiej, a „przyjaciółki pani Borzymowiczowej, pomagające dzielnie w wysadzaniu nowatorek z posad, porwały tę wieść i niosły ją po miasteczku, niby huragan liście" (S1, s. 328-329). Podczas zabawy z okazji zaręczyn pracownika apteki Borzymowiczów kobiety wymieniały następujące uwagi:

\section{\ ta panna $\mathrm{z}$ apteką to niezła partia - mówiła amatorka ciastek. - Dajże pani pokój! - zaperzyła się Borzymowiczowa. - A to dopiero! Któżby tam chciał taką osławioną za żonę! - Coś teraz przycichła, nigdzie jej nie widać; może już i wstyd pokazywać między ludźmi - wtrąciła kapitalistka, która, mając trzy tysiące funduszu, zarabia drugie}

24 Zurakowska uprzedmiotowiała przy tym tę kobietę, przedstawiając ją bratu jako coś, co musi zdobyć, bo będzie mu się to opłacało (W, s. 26).

25 Negatywnie nastawiona do Starkiewiczówny była także jej wychowanica, Wicia, która celowo, by sprawić kobiecie przykrość, powiedziała jej o ślubie Czesława i Teresy (W, s. 306, 224) oraz o tym, że prawdopodobnie straci pracę przed Bożym Narodzeniem ze względu na zmiany planów matki co do kształcenia dzieci (W, s. 230-231).

26 Zob. J. Wasilewski, op. cit., s. 295. 
tyle rocznie $z$ procentu lichwiarskiego. - E, takie tam nie wstydzą się ani Boga, ani ludzi!

- Prawda!... święta prawda!... Nigdy ich w kościele nie widać; moja córka chodzi co dzień na nabożeństwo i siedzi w kościele od prymarii dopóki kościoła nie zamkną, wie zatem dobrze, kto tam bywa najczęściej i powiada, że nigdy tych panien nie widuje, chyba czasem w niedzielę. - Że też ich ziemia nosi - zajęczały pobożne duszyczki (S1, s. 4I2-4I3).

Z odrzuceniem i agresją innego rodzaju spotkała się Hanna, gdy zamiast Nory pracowała charytatywnie - głównie pomagając i ucząc dzieci robotnic. Kontakty te różniły się od zawodowych o tyle, że nie wynikały z odgrywania przez ich uczestników odmiennych ról społecznych (pracodawca versus podwładny) czy konkurencji między firmami. Instytucja tworzyła w tym wypadku przede wszystkim wspólną przestrzeń do dobrowolnych relacji z ludźmi o odmiennych doświadczeniach życiowych i różnych postawach, przez co miały one bardziej prywatny niż formalny charakter. Początkowo kobieta miała zajmować się przywożeniem listów oraz paczek od rodzin do więźniów. Jednak szybko musiała zrezygnować, gdyż komitetowi przeznaczającemu na to pieniądze nie spodobała się reputacja Hanny (Kzp, s. II3-II4). Następnie bohaterka zajęła się rozdzielaniem darów oraz działalnością oświatową wśród ubogich dzieci.

Hannie przydzielono pomocnicę, Leokadię, która często ją obrażała, lecząc w ten sposób swoje własne kompleksy.

\Wykpiwała otwarcie ofiarność „burżujów”, którzy znaleźli nowy rodzaj zabawy, tworząc komitety, zebrania i inne szopki i mówiła lekceważąco o paniach, podejmujących się różnych prac społecznych.

- Nie mają co robić z czasem, lafiryndy, ani gdzie prezentować pudeł na głowach, to urządzają posiedzenia dla „pracujących”. Niby to o nas mówią i aż pękają z zazdrości, która lepiej brzuch wciągnie w gorset. Znamy się na tym!

Z przyjemnością przynosiła różne złe wieści Hannie. [...] W mowie jej czuć było nienawiść kastową zapracowanej od dzieciństwa, głodzonej i wyzyskiwanej pracownicy o grubych rękach, popierzchłej twarzy, do delikatnej, estetycznej kobiety, mówiącej głosem modulowanym, poruszającej się miękko, prześlicznie (Kzp, s. II5).

Zaczepki kobiety wynikały również z odczuwanego przez nią zagrożenia, gdyż Stach, którego darzyła uczuciem, wciąż wpatrywał się w Hannę i był nią zainteresowany. Pewnego dnia Leokadia nie wytrzymała napięcia i wybuchła gniewem: 
\-Mówię prawdę [...], że ta pani nic lepszego od nas, a może i gorsza. To, że grzechy przykrywa piękną suknią, to każda „taka” potrafi. [...] Ale takiej nie popuszczę, co niby skromna, niby dobrodziejka, ofiarnica, a z chłopami się zadaje... Każdego by na swoją stronę przeciągnęła. Abo to ona dla nas przychodzi... dla robotnic? Dla chłopów naszych przychodzi... Tylko dla nich! [...]

- Mówię prawdę! Stach sam mi opowiadał, że spotkał tę pannę, jak się po przedmieściu włóczyła. Chciał ją w krzaki zaciągnąć. Uciekła mu. Śledził gdzie mieszka, i u stróża [...] dowiedział się, że panna ma bękarta i że mężczyzn przyjmuje (Kzp, s. I62-163).

\section{RELACJE PRZYGODNE, Z NIEZNAJOMYMI}

Relacje przygodne (Piotr Sztompka używa na ich określenie pojęcia „kontakty społeczne") od strony formalnej zasadniczo różnią się od analizowanych wcześniej stosunków i więzi międzyludzkich, a także od interakcji społecznych ${ }^{27}$. Mimo to charakteryzowały się tymi samymi mechanizmami postępowania ich uczestniczek oraz używaniem przez nie podobnego języka - wszelkie zachowania niestandardowe bądź niewpisujące się w jedną przyjętą rolę prowadziły do ostracyzmu nie tylko ze strony kobiet bliskich (należących do rodziny, przyjaciól lub znajomych), ale także zupełnie obcych.

\section{Reakcje na kobietę $\mathrm{z}$ „bękartem”}

Jak wspomniałam, omawiając relacje sąsiedzkie, ostracyzmu doświadczała nie tylko Hanna, ale także niania, opiekująca się jej córką Wiesią i pomagająca w gospodarstwie domowym. Pewnego dnia, pod nieobecność matki dziewczynki, odwiedziła ją nieznajoma kobieta „Z różańcem w ręce i paczką książek do nabożeństwa”, proponując, że za drobną opłatą będzie modlić się za Wiesię o zmiłowanie boskie. Gdy rozłoszczona niania odpowiedziała, że dziecko nie popełniło żadnych grzechów i nie potrzebuje prosić o przebaczenie, usłyszała: „Wiedziałam, że w tym występnym domu spotka mnie zniewaga. Próżno skalałam swe szaty, wchodząc tu w imię Chrystusa”, a na odchodnym obrażona dewotka przeklęła: „Bodaj was pochłonęło

27 O ile kontakty społeczne mają charakter krótkotrwały, przelotny, zachodzą głównie między nieznajomymi w miejscach publicznych, np. na ulicach, w parkach, o tyle interakcje nie mają charakteru jednorazowego, bywają rozciągnięte w czasie i mają od nich bogatszą treść. Zob. P. Sztompka, Kapitat spoteczny..., op. cit., s. 120-124. 
piekło razem z tym bękartem!” (Kzp, s. 2O-2I). Nieco później „pobożna kobieta” skomentowała to wydarzenie także publicznie:

》 - Ta stara nikczemnica, która ma trzy dni do śmierci, zamiast spędzać czas na modlitwie, leżąc na podłodze, w przedsionku kościoła, oddała się na usługi grzechu. Służy u ladacznicy i oprowadza się z tym pomiotem szatańskim (Kzp, s. 26).

Spacerując $z$ Wiesią po parku, niania pragnęła chronić małą przed odtrąceniem i obelgami, dlatego też dbała o to, co i do kogo mówi: „odpowiadając uprzejmie, wymijająco na zapytania bon i służących, umiejętnie manewrując, żeby nie powiedzieć za wiele i żeby suchością odpowiedzi nie obrazić gadatliwych srok" (Kzp, s. 24). Unikała zwłaszcza osób znajomych, a kiedy pojawiało się najmniejsze niebezpieczeństwo, zabierała dziecko i odchodziła. Kiedyś Wiesia zapytała: „Od czego my, nianiu, uciekamy? [...] - Od podłości i głupoty ludzkiej - odpowiedziała rozżalona niania" (Kzp, s. 24-25).

Po śmierci niani takiej ochrony zabrakło, nic więc dziwnego, że dziecko zapytało kiedyś Hannę:

$$
\begin{aligned}
& \text { - Mamusiu, co to takiego bękart? } \\
& \text { Hanna drgnęła. } \\
& \text { - Skąd słyszałaś to... słowo? } \\
& \text { - Dziś chodziłam do sklepu z Tomaszową, i jakaś kobieta tak mnie } \\
& \text { nazwała. } \\
& \text { - Nie będziesz więcej wychodzić z Tomaszową. } \\
& \text { - Nie chcę wychodzić. Wszyscy na mnie się gniewają. [...] Kiedyś } \\
& \text { także wyszłam na podwórze, a ten chłopak z drugiego piętra zaraz } \\
& \text { krzyknął: „Uciekajcie, ta mała idzie! Mama znów będzie się gniewała, } \\
& \text { gdy ona się do nas zbliży”(Kzp, s. I50). }
\end{aligned}
$$

Gdy osaczona Hanna sprzedała mieszkanie i postanowiła wynająć pokój za mniejsze pieniądze, dwudniowe poszukiwania stały się dla niej ciągiem upokorzeń. Właścicielki były miłe tylko do momentu, gdy dowiadywały się o nieślubnym dziecku:

》 Niektóre panie żegnały ją wnet chłodno i bez ceremonii, inne zbywały delikatniej obawą kłopotu. W jednym domu, wychodząc, usłyszała:

- Ależ arogantka! Tak śmiało mówiła o tym... Powiadam ci, zdębiałam. Któraś z litościwszych, mająca kilkoro dzieci, radziła, żeby małą oddać do domu podrzutków (Kzp, s. I52). 
Z kolei od młodej mężatki Hanna usłyszała:

\-Bardzo bym chciała... Ale, doprawdy nie wiem... Nie jestem siłą decydującą. Mój mąż takich surowych zasad... Nie zgodzi się zapewne. Jestem w danym wypadku bezsilna. Wreszcie nie chciałabym wpływać na zmianę jego przekonań. Dla nas, żon - dodała poufnie - lepiej, jeżeli mężowie mają surowe zasady. Jesteśmy bezpieczniejsze. [...] - Patrzyła na Hannę z ogromnym zajęciem. - Więc to tak wygląda kobieta wolna, wyparta za kordon uczciwych kobiet, nie mająca dostępu do europejskiego haremu, zwanego chrześcijańskim małżeństwem - myślała (Kzp, s. 153).

Zmagania Hanny z opinią społeczną trafnie obrazował jeden z jej snów. Oto stała przed miastem, trzymając na rękach głodną Wiesię. Były zmarznięte i zmęczone, jednak za każdym razem

\Kordon - sznur kobiet i mężczyzn, zaczepionych o siebie rękami, bronił wejścia. Skoro chciała zbliżyć się, zacieśniano ręce. [...] A ona wciąż chodziła $\mathrm{z}$ dzieckiem $\mathrm{w}$ ramionach, pokaleczonymi nogami, w poszarpanym ubraniu, samotna, odepchnięta - wieczna Agar (Kzp, s. I49).

Nawet gdy oddała Wiesię na wychowanie bezdzietnej, znajomej parze, to choć nie miała już problemu $\mathrm{z}$ wynajęciem pokoju, to i tak - ze względu na otaczającą ją aurę tajemniczości - gospodynie traktowały ją podejrzliwie i wrogo:

\ - Co to za jedna? Tajemnicza, nie można od niej dowiedzieć się słowa. Cały dzień, diabli wiedzą, gdzie się włóczy, wraca wieczorem, jak z krzyża zdjęta. Rzeźbiarka czy modelka?

- Bajecznie zbudowana. Modelka niechybnie! - zapewniał syn.

- A, to bardzo dziękuję za taką lokatorkę! Cały dzień w pracowni $\mathrm{z}$ artystami. Wyobrażam sobie, co tam dziać się musi.

Czepiała się Hanny codziennie. Szklanka, nóż wzięty nie w porę, przelana woda na posadzce, wszystko było powodem cierpkich wymówek (Kzp, s. I8I-182).

Inna gospodyni wypowiedziała jej lokum na skutek częstych wizyt Janka, z którym znała się jeszcze z czasów charytatywnej pomocy więźniom:

\ - Przyszłam powiedzieć, żeby pani sobie mieszkania szukała. Do północy u pani mężczyźni przesiadują. Jakieś szepty, szlochy. Tu, u mnie, 
mieszkają tylko uczciwe kobiety. U mnie nie ma miejsca dla takich, co chcą sobie na wolną rękę życia używać. [...]. Mówiłam, żeby pani sobie szukała pokoju, bo u mnie mogą mieszkać tylko uczciwe kobiety (Kzp, s. 190).

Nie lepiej układały się też jej stosunki ze współlokatorkami. Owe młode kobiety, które cały czas mówiły i myślały o mężczyznach, wyśmiewały ładne znajome i plotkowały, zaczęły ją śledzić, otwierać listy ( $z$ nich dowiedziały się o nieślubnym dziecku), tworzyć o niej „baśnie, kłamliwe, pełzające, którymi się bawiły mózgi domowych pań” (Kzp, s. I82).

\section{Stosunek do prostytutki}

Zjawisko prostytucji, nieobecne w zasadzie w rozmowach „przyzwoitych kobiet”, było poważnym problemem społecznym. Osoby trudniące się nierządem usuwano na margines i poniżano. Widać to choćby po reakcji przechodniów w sytuacji której świadkiem była Hanna - gdy jedną z nich, niemającą odpowiedniego dokumentu (tzw. książeczki), zatrzymał stójkowy: „Kilku mężczyzn przypatrywało się widowisku, dowcipkując. Parę kobiet stało na uboczu zmieszanych, przelęknionych" (Kzp, s. 84). Co więcej, gdy przestraszonej dziewczynie udało się wyrwać, jakiś mężczyzna podstawił jej nogę, a inni rzucili się w pościg. Gdy Hanna chciała zareagować, znajoma rzeźbiarka siłą odciągnęła ją od zbiegowiska. „Niech pani o tym nawet nie myśli. [...] Pomyślą, że jesteśmy jej towarzyszkami i nas zabiorą. Na nic byłoby usprawiedliwianie się" (Kzp, s. 85). Wydarzenie to zrobiło na Hannie ogromne wrażenie:
\Wracała wciąż myślą do nieszczęśliwej prostytutki, którą bito przed kilkoma godzinami. [...] Bito kobietę za to, że nie chciała największe- go występku: sprzedaży ducha i ciała, zaregestrować w księgę prawa, że wzbraniała się wziąć na siebie odpowiedzialności za zbrodnię, którą jej narzucano. Czy podlega mężczyzna, pracujący w jakimkolwiek bądź fachu, podobnemu pohańbieniu, podobnemu gwałtowi? A więc tylko kobieta! (Kzp, s. 88).

Mężczyźni są sędziami, którzy ,jawią się jako kompetentni, poinformowani dysponenci prawdy i działający w dobrych intencjach wobec tych, którzy zbłądzili”" ${ }^{28}$, kobiety zaś biernie i milcząco przyglądają się sytuacji. Stosowanie przemocy wobec 
prostytutki wydaje się im uzasadnione - dziewczęta takie stanowią zagrożenie dla rodziny, deprawują bowiem mężczyzn, a w dalszej konsekwencji społeczeństwo ${ }^{29}$ - więc kobiety nie reagują na agresję.

\section{Podsumowanie}

Niedźwiedzka nie poprzestawała na opisach pojedynczych sytuacji. W jej powieściach znaleźć można także przenikliwe diagnozy przyczyn toksycznych relacji między kobietami

》 [Hanna - B.W.] Zmieniała mieszkanie i wchodziła w królestwa, gdzie niepodzielnie rządzą kobiety. Poznawała ich małostki, ich nieznośne wady i wielkie dostojeństwa, i wielkie nieszczęścia, ich walkę o byt i o mężczyznę. [...]

Hanna będąc wtajemniczoną w życie kobiet, u których mieszkała, spostrzegła,że w rodzinie kobieta jest często ofiarą, a zarazem tyra nem [wyróżn. B.W.], że wrodzony popęd do wzniosłych czynów i wielkich zbrodni, zdrobiazgowany na lichym podłożu codziennych karlich walk, doprowadza ją do czynów głupich, niekiedy okrutnych.

Spostrzegła, że kobieta ma ogromny na ogół wpływ, idący korytem podziemnym nieraz ze zgniłych bagien.

I właśnie ten mus ukrywania swoich rzeczywistych myśli, to ciągłe maskowanie się, ciężka i upokarzająca walka, czyniły ją małostkową i okrutną.

Największą czeęść swojej niedoli Hanna zawdzięcza kobietom. Och, jakże wiele z nich było Iwanami Groźnymi, Napoleonami, Torkwemadami, Sawonarolami! (Kzp, s. 183) $)^{30}$.

Według pisarki kobieta uczestniczyła więc w relacjach społecznych na dwa sposoby: pasywnie, jako poddająca się dominacji oraz narzuconemu przez mężczyzn wzorcowi kobiecości i męskości, a także aktywnie - jako cenzor i oprawca innych kobiet. Jej wnioski zgodne są z wynikami analiz współczesnych badaczy, twierdzących, że męska dominacja została „wcielona w postaci nieświadomych schematów

29 J. Zacharska, Prostytutka - kobieta upadta czy wyzwolona?, w: eadem, O kobiecie w literaturze przetomu XIX i XX w., Białystok 2000, s. 145, 152.

30 Zob. też Sł, s. 209-214. 
percepcji i oceny" ${ }^{3 \mathrm{r}} \mathrm{i}$ ugruntowana przez porządek społeczny na drodze przemian historycznych. Taka postawa kobiet nie powinna dziwić, ponieważ

\section{\ „Zasilane” zasadami widzenia pochodzącymi z takiego samego do- świadczenia świata, wcieliły zasady dominującej wizji [...], która pro- wadzi je do uznania normalności, a nawet naturalności istniejącego porządku społecznego jako przeznaczenia i w pewnym sensie „wy- przedzania” go wyrażającego się w odmowie podejmowania kształcenia lub pracy w dziedzinach, z których są już wykluczone, i gorliwego podejmowania tych, które się im powierza ${ }^{32}$.}

Ten arbitralnie narzucony porządek stał się elementem fundującym rzeczywistość i był odbierany jako coś naturalnego, oczywistego, a wszelka próba jego zmiany spotykała się z różnego typu sankcjami społecznymi.

Najważniejszymi instytucjami, które ów mechanizm dominacji utwierdzają, są rodzina, Kościół i szkoła. To matka - poprzez system zakazów i nakazów - wpaja córce wzorzec kobiecości i przygotowuje ją do życia w męskim społeczeństwie ${ }^{33}$ w myśl uniwersalnej maksymy: „To dla twojego dobra”34. Stosunki matka-córka opisywane przez Niedźwiedzką cechował paternalizm eksploatacyjny. Kiedy potrzeby dziecka pokrywały się z tymi, które preferowała rodzicielka, relacje były dobre. W przeciwnym wypadku między partnerkami relacji dochodziło do napięć, a potrzeby potomka były trywializowane i ignorowane (przykładem może być rozmowa chcącej podjąć studia Hali z matką) $)^{35}$.

Wartość kobiety zdeprecjonowała nauka Kościoła oparta na chrześcijańskim micie założycielskim, czyli opowieść o Adamie i Ewie. Nie dziwi więc, że Walska,

31 P. Bourdieu, op. cit., s. 13.

32 Ibidem, s. 113.

33 Odbywa się to (jak w opisanych wyżej relacjach matka-córka) za pomocą działań dyscyplinujących, które Michel Foucault (Nadzorować i karać, tłum. T. Komendant, Warszawa 2009, s. 132-133, 138, 175) zalicza do powszechnie praktykowanych form dominacji. Ich charakterystycznymi cechami są m.in. stosowanie subtelnego wpływu na pewne elementy szczegółowe (jak np. ruch, postawę, gest), a nie na całość w ogóle, czy wypracowanie mechanicznego powtarzania działań bez pytania o ich cel. Skutkuje to ujarzmianiem podmiotu i relacjami nacechowanymi stosunkiem „podatność-przydatność". Dyscyplinowanie musi zachodzić w specjalnie wydzielonym obszarze/przestrzeni/lokum, ponieważ „Trzeba mieć informację o obecności i nieobecności, wiedzieć kiedy i jak każdego znaleźć, umożliwić kontakty pożyteczne, a przeciąć szkodliwe, móc w każdej chwili nadzorować zachowanie każdego, ocenić je, zareagować, wyliczyć zalety i zasługi”. Za nieprzestrzeganie dyscypliny grożą kary (np. gniew matki, w szerszym aspekcie - sankcje społeczne), a jej celem jest zmniejszenie liczby osobników podejmujących aktywność wykraczającą poza granice obowiązującej normy.

34 J. Wasilewski, op. cit., s. 269.

35 Ibidem, s. 273. Przeciwieństwem jest paternalizm benefakcyjny, opierający się na zaufaniu i autorytecie oraz zawierający motyw „uwolnienia”, tj. zyskania przez dziecko niezależności i autonomii. 
rezydentka domu Czatyhorskich, twierdziła: „kobieta nie powinna równać się z mężczyzną; Pan Bóg dał mu siłę i rozum, a jej co?... tylko włosy długie [...]" (S1, s. I34) i opowieść o swoim życiu kończy stwierdzeniem, że kobiety pokutują, bo Ewa zwiodła Adama. Według Hali,

\section{\} \quad \text { [to - B.W.] ta niedorzeczna i śmieszna bajka, miała straszne następ- } stwa dla kobiety [...] stawiając ją w świetle chrześcijańskim, jako winowajczynię nędz ludzkich. W imię tej bajki została ujarzmioną przez mężczyznę, zepchniętą do stanowiska niewolnicy, sługi posłusz- nej panu; a duch jej sterroryzowany, zdemoralizowany ciągłą krzywdą, uwierzył w niepopełnioną swą winę (S1, s. I35).}

Ponieważ nauka mogłaby podważyć zasadę, że „kobiety mogą stać się jedynie tym, kim są" ${ }^{36}$, ambitniejsze plany edukacyjne dziewcząt starano się zdusić w zarodku (np. przez konfiskatę zakazanych książek czy - jak w wypadku Haliny Czatyhorskiej - stosując szantaż i nie udzielając jakiejkolwiek pomocy finansowej). Edukacja powinna utwierdzić w dziewczętach „naturalne” powołanie i gwarantować, że nie będą przekraczały wyznaczonych im granic. Nauka dyscyplinowania ciała - odpowiedniego poruszania się, czesania, noszenia strojów i biżuterii, a także prowadzenia rozmów z mężczyznami - służyła „ciągłemu przypominaniu o obowiązującym porządku"37, w którym kobiece ciało miało być ciałem-dla-innego, konstruktem męskich potrzeb i oczekiwañ $3^{8}$.

Sposób wychowywania przez matki powodował, że młoda kobieta stawała się przedmiotem wymiany,

\section{\ jest zredukowana do statusu narzędzia produkcji i reprodukcji kapitału symbolicznego oraz społecznego. [...] Jest jedyną możliwą postacią jego akumulacji, [...] która musi pozostać poza wszelkim podejrze- niem (czy „skalaniem”), ponieważ zainwestowane w wymianę tworzą związki, to znaczy kapitał społeczny, a także prestiżowe przymierza - kapitał symboliczny. A zatem jeśli wartość tych związków (sym- boliczny zysk) zależy od wartości symbolicznej samych kobiet (tzw. reputacji, a zwłaszcza czystości, które są przez mężczyzn fetyszyzo- wane i traktowane jako kapitał symboliczny całej linii), paranoidalna czujność mężowska [...] jawi się jako troska o dobrze pojęty interes.}

36 P. Bourdieu, op. cit., s. 42.

37 Ibidem, s. 40.

38 Ibidem, s. 82. 
To dlatego matki dbały o to, żeby młode kobiety nie mogły przebywać nawet przez krótką chwilę sam na sam z młodym mężczyzną czy zawierać znajomości mogących zepsuć ich reputację.

Niewątpliwie część scharakteryzowanych zachowań kobiecych była pokłosiem zinternalizowania męskiego punktu widzenia i przebiegało według schematu niewolniczego. Pragnienia i potrzeby dziewcząt oraz kobiet rugowano i marginalizowano. Mimo to często powracały, a niemożność ich realizacji budziła negatywne emocje: od frustracji, żalu, złośliwości, zawziętości po gorycz i niezadowolenie. Musiały je na kimś wyładować, więc często wybierały słabszych od siebie, a zatem inne kobiety, zwłaszcza te, które odstawały od standardów obowiązujących w danym środowisku. To one odgrywały rolę tzw. kozła ofiarnego. Manifestowanie swej pozornej przewagi polegało często na ignorowaniu innych (jak np. podczas balu u Monińskich - S1, s. 280), na celowym unikaniu kontaktu wzrokowego czy nieodpowiadaniu na gesty powitania (Kzp, s. I28-I29). Ową przewagę wzmacniał wyczuwalny brak życzliwości, co powodowało u ofiary takie objawy jak drżenie głosu, jąkanie się, zagryzanie warg, ucieczkę od rozmowy (Dm, s. Io-I7). Ponieważ „Osoby dominujące [...] mają potrzebę odróżnienia się od podporządkowanej reszty znakami statusu, natomiast ci usytuowani niżej, chcąc poczuć się lepiej, uprawiają swoiste naśladownictwo, mimikrę prestiżu" ${ }^{39}$, taką strategię przyjęła pani Drużbecka, próbując kopiować styl życia i metody wychowania córek, które podpatrzyła u dziedziczki Czatyhorskiej. Ale ona też spotkała się z lekceważeniem, drwinami i śmiechem.

W omawianych powieściach odnaleźć można także przykłady złośliwych zachowań wynikających z biologii, przybierających postać instynktownej zazdrości o uwagę mężczyzny (np. chęci zdeprecjonowania w jego oczach potencjalnej rywalki; zob. głośne komentarze dotyczące stroju Ruty czy planowane przez Teresę zniszczenie materiału na sukienkę dla Ewy Starkiewiczówny - W, s. 95) lub walki o miejsce i uznanie w grupie.

Wydaje się więc, że za podsumowujący komentarz na temat zrekonstruowanych przeze mnie relacji między kobietami mogą posłużyć dwie opinie wypowiedziane przez bohaterów powieści Niedźwiedzkiej: Hannę - „Kobiety wiecznie oszukują siebie i innych. Smaga je za to życie, smagają ci, co umieją dyktować prawa" (Kzp, s. 36) oraz Henryka Orzelskiego z Naszych dekadentów - „Kobiety są bardzo głupie, [...] otwierają im wrota do swobody, do jakichś praw ludzkich, a one nie tylko nie korzystają z tego, ale najwięcej potępiają te spomiędzy siebie, które owe wrota przekroczyły" ${ }^{40}$. 
Jak się wydaje, do określenia miejsca powieści Niedźwiedzkiej w dziejach gatunku można by zasadnie użyć formuł Wilhelma Feldmana:

\section{\Obok literatury w wielkim stylu, literatury-sztuki, reprezentatywnej, literatury indywidualności wielkich, jest druga, o znacznie skrom- niejszej sile, sztuka stosowana, służebnica życia codziennego, piekąca chleb konieczny dla szerokich warstw całej i pseudo-inteligencji. [...] Literatura ta [...] ukazuje nam, w co przemieniają się w praktyce wiel- kie idee i wielkie objawienia artystyczne prawdziwych twórców; jak one odbijają się w świadomości tłumu czytającego, na jakim poziomie przeciętności ta stoi ${ }^{41}$.}

Tajemnicą wspomnianej wcześniej popularności utworów Bohowityna była bowiem łatwość ich odbioru. Choć bohaterki powieści wywodziły się z różnych środowisk społecznych (arystokracji, szlachty, inteligencji, mieszczaństwa, służby domowej, a nawet $\mathrm{z}$ marginesu społecznego), to ich problemy i reakcje nie przekraczały horyzontów intelektualnych i mentalnych ówczesnych odbiorców. Także dzisiejszy czytelnik z łatwością dostrzega w nich motywy, sytuacje, rozwiązania fabularne, rozstrzygnięcia etyczne, a nawet formuły językowe znane mu $\mathrm{z}$ innych tekstów pochodzących z epoki - z utworów Marii Rodziewiczówny, Gabrieli Zapolskiej, Celiny Gładkowskiej, Anieli Kraszewskiej, Hanny Krzemienieckiej i wielu innych autorek ${ }^{42}$. Granice prezentowanego szkicu nie pozwalają na zilustrowanie tego zjawiska przykładami, nie mam jednak wątpliwości, że - przy zastosowaniu odpowiednich procedur badawczych - powieści omawianego typu można traktować jako bogate źródło informacji o ówczesnej rzeczywistości, a zwłaszcza o sposobach jej postrzegania. $Z$ tego samego powodu nie próbowałam weryfikować poszczególnych faktów lub zachowań z innymi źródłami wiedzy, takimi jak pamiętniki, zbiory korespondencji, a także istniejąca literatura przedmiotu ${ }^{43}$.

41 W. Feldman, Wspótczesna literatura polska, wyd. 5, Lwów-Warszawa 1908, s. 95.

42 Gromadzona przeze mnie lista polskich autorek powieści opublikowanych osobno w latach 1865-1905 liczy obecnie ponad 80 nazwisk, a spis tekstów spełniających to kryterium obejmuje bez mała 250 tytułów.

43 Literatura na temat problemów życia codziennego w XIX i początkach XX w., jeśli nawet ograniczyć się tylko do mieszkanek ziem polskich, jest bardzo liczna i systematycznie rośnie, zwłaszcza od lat dziewięćdziesiątych XX w. Wystarczy wspomnieć o dziewięciu tomach studiów z cyklu „Kobieta i społeczeństwo na ziemiach polskich w XIX w.”, pod red. Anny Żarnowskiej i Andrzeja Szwarca, które ukazały się w latach 1990-2006. Sporo interesujących informacji zawierają też prace historyków na temat poszczególnych warstw społecznych (ziemiaństwa, inteligencji, mieszczaństwa - także żydowskiego) i niektóre opracowania historycznoliterackie (np. na temat wspomnianej Zapolskiej). 


\section{Bibliografia:}

Bourdieu P., Męska dominacja, tłum. L. Kopciewicz, Warszawa 2004;

Czepulis-Rastenis R., Znaczenie prozy obyczajowej XIX wieku dla badań ówczesnej świadomości i stosunków spotecznych, w: Dzieło literackie jako zródto historyczne, red. Z. Stefanowska i J. Sławiński, Warszawa 1978, s. 261-281;

Dunaj-Dziecielska K., Dobry duch domu i „Belzebub w spódnicy”, czyli portrety ciotek w powieści „Nasi dekadenci" Zofii Niedźwiedzkiej, w: Do ostatniego lokaja... W kręgu rodziny i znajomych, red. K. Eremus i T. Linkner, Gdańsk 2013, s. 47-55;

„Umiem kochać tylko krótkotrwata namiętnościa wędrowca”. Portret amanta w „Dziejach mężatek” Zofii Niedźwiedzkiej, w: „Wszystko lubię to, co pani...”. Literackie portrety amantów i studentów, red. K. Eremus i T. Linkner, Gdańsk 2013, s. 105-115;

O „takich” sięnie mówi, czyli „Kobieta z przesztościa” Zofii Niedźwiedzkiej, w: Cate miasto dysze oburzeniem... Skandal w literaturze XIX i XX wieku, red. K. Eremus i T. Linkner, Gdańsk 2012, s. 63-71;

Sitaczki, emancypantki, dekadentki. Galeria postaci kobiecych w powiesci „Nasi dekadenci” Zofii Niedźwiedzkiej, w: Znane zapomniane. Z literatury polskiej XIX i XX wieku, red. K. Eremus i T. Linkner, Gdańsk 2011, s. 81-96;

Twórczośc literacka Zofii Niedźwiedzkiej (pseudonim Bohowityn) - wybrane problemy, niepublikowana praca doktorska napisana pod kierunkiem prof. T. Linknera, obroniona w 2013 r. na Wydziale Filologicznym Uniwersytetu Gdańskiego;

Foucault M., Nadzorować i karać, tłum. T. Komendant, Warszawa 2009;

Geremek B., Fabuta, konwencja i źródto, w: Dzieto literackie jako źródto historyczne, op. cit., s. 114-145;

Głowiński M., Powieśc i prawda, w: idem, Gry powieściowe. Szkice z teorii i historii form narracyjnych, Warszawa 1973, s. 9-36;

Jopek A., Niedżwiedzka z Kozieradzkich Zofia, w: Polski stownik biograficzny, t. 22, Wrocław 1977, s. 754;

Kostecki J., Rowicka M., Biblioteki w zaborze rosyjskim w powieściach realistycznych II potowy XIX wieku, w: Biblioteki i ksiqżki w literaturze, red. K. Bednarska-Ruszajowa, Kraków 1998, s. 75-91;

Niedźwiedzka Z., Dzieje mężatek, Lwów 1919;

Kobieta z przesztościa, Lwów 1923;

Nasi dekadenci, t. 1, Warszawa [1922];

Stoneczniki, Warszawa 1901;

Wyzyskiwani, Warszawa 1903;

Rowicka M., Sceny lektury w polskiej powieści realistycznej drugiej potowy XIX w. (zabór rosyjski), w: Instytucje - publiczność-sytuacje lektury. Studia, pod red. J. Kosteckiego, t. 3, Warszawa 1991, s. 98-180;

Sztompka P., Kapitat spoteczny. Teoria przestrzeni międzyludzkiej, Kraków 2016;

Życie codzienne - temat najnowszej socjologii, w: Socjologia codzienności, pod red. P. Sztompki i M. Boguni-Borowskiej, Kraków 2008, s. 15-52;

Szweykowski Z., Maciejewski J., Literatura pozytywizmu i Mtodej Polski: hasła osobowe M-Ś. Bibliografia Literatury Polskiej „Nowy Korbut”, t. 15, Warszawa 1977, s. 110-111;

Teresińska I., Niedźwiedzka Zofia, w: Dawni pisarze polscy: od poczatków piśmiennictwa do Mtodej Polski: przewodnik biograficzny i bibliograficzny, t. 3: Mia-R, Warszawa 2002, s. 125;

Topolski J., Problemy metodologiczne korzystania ze źródet literackich w badaniu historycznym, w: Dzieto

Ogólny zarys problematyki zawiera książka Obyczaje w Polsce. Od średniowiecza do czasów wspótczesnych, red. A. Chwalba, Warszawa 2004. 
literackie jako źódto historyczne, op. cit., s. 7-30;

Uliński M., Etyka troski i jej pogranicza, Kraków 2012.

Wasilewski J., Retoryka dominacji, Warszawa 2006.

Zacharska J., Prostytutka - kobieta upadta czy wyzwolona?, w: eadem, O kobiecie w literaturze przetomu XIX i XX w., Białystok 2000, s. 139-159.

SŁowa klucze: Zofia Niedźwiedzka, negatywne relacje między kobietami, męska dominacja

\section{BARbARA WĄSIK}

UNDER SCRUTINY - DIFFICULT RELATIONSHIPS BETWEEN WOMEN IN THE NOVELS By Zofia NiedźwiedZKa

Women have various relationships between themselves: I) family relations, 2) social relations, 3) neighbourhood relations, 4) professional relations and other relations connected with non-professional activities, 5) incidental relations. These relations are both positive and negative. The latter in the chosen novels by Zofia Niedźwiedzka have been analysed and both the strategies of the attackers and the defenders have been taken into account. The observations focused on parts of life which are usually evaluated (such as: background, looks, beliefs, aspirations and the style of life), and also on social sources of the criteria used by women. The answer to the question was searched whether these criteria are the product of the internalization of norms imposed by men ("masculine domination", how Pierre Bourdieu would put it) or whether they depend on some other factors.

KEY worDs: Zofia Niedźwiedzka, negative relationships between women, masculine domination 